
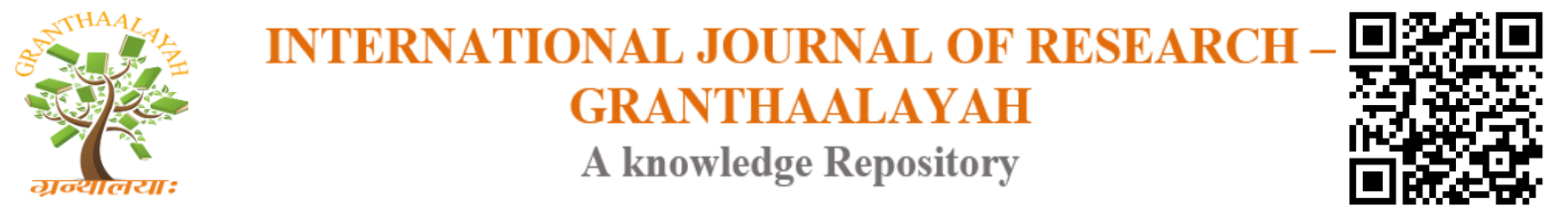

Science

\title{
NEW SUPERIOR VARIETY ADAPTATION AND NUMBER OF BREEDS ON PRODUCTIVITY LOWLAND RICE
}

\author{
Sution ${ }^{1}$, Laurensius Lehar *2 \\ ${ }^{1}$ Assessment Institute for Agricultural Technology of Wast Kalimantan, Indonesia. \\ *2 Department Food Crops and Horticulture, State Agricultural Polytechnic of Kupang, Indonesia
}

\begin{abstract}
This study aims to obtain new adaptive superior varieties, obtain the appropriate number of seeds and produce a combination of technological packages between varieties and the number of suitable seeds to increase productivity lowland rice. The design used was factorial Randomized Block Design (RBD) consisting of 2 factors, namely the first factor of the variety consisted of Ciherang, Inpari 30 and Inpara 2. The second factor was the use of the number of seeds consisting of 2 stems, 5 stems, 8 stems, and 11 stems. The second combination was 12 treatments, which were repeated 3 times, overall there were 36 trial plots. The results showed that the productivity of Inpara 2 varieties of rice gave an increase in yield of $36.82 \%$ harvested dry grain compared to the Ciherang variety which is an existing variety. The use of 2-11 stems is not significant for plant productivity, but only affects the amount of filled grain and the number of grains per panicle, in the treatment of the number of seeds of 8 stems. Inpari 30 varieties with 2 and 5 stems have the highest 1000 grains of 25.89 and $25.81 \mathrm{~g}$, respectively.
\end{abstract}

Keywords: Varieties; Seeds; Adaptation; Productivity; Lowland Rice.

Cite This Article: Sution, and Laurensius Lehar. (2019). "NEW SUPERIOR VARIETY ADAPTATION AND NUMBER OF BREEDS ON PRODUCTIVITY LOWLAND RICE." International Journal of Research - Granthaalayah, 7(8), 446-453. https://doi.org/10.29121/granthaalayah.v7.i8.2019.698.

\section{Introduction}

The need for rice as the main food source of Indonesia's population continues to increase, along with the rate of population growth and the high level of national rice consumption which is still high. The achievement of rice production targets continues to increase, along with increasing national food needs. One of the Ministry of Agriculture's Strategic targets for 2015-2019 is food self-sufficiency, especially rice commodities, where the production target in 2017 is 78.13 million tons and in 2019 to 82.08 million tons (Ministry of Agriculture, 2015). Indonesia as a country with a large population faces challenges in meeting the food needs of the population. Therefore, food security policies are the main focus of agricultural development. One effort was made to increase rice production with the use of new adaptive superior varieties and cultivation technology, one of 
which is the use of the right number of seeds. The results of the research on the use of superior varieties have a very prominent role in efforts to increase rice productivity (Kiswanto and Adriyani, 2011). The new superior varieties of rice play an important role in changing the pattern of subsistence agriculture to be commercial, with a level of productivity three times that of local varieties. Superior varieties have characteristics of short stems, upright leaves, and many tillers so that they have the ability to intercept greater sunlight so that the long photosynthetic process runs well and will produce more grain (Suprihatno and Dradjat, 2009).

Increased rice productivity causes a decrease in the efficiency and effectiveness of inputs, characterized by the increase in yields, reduced fertility of paddy fields, and the increasing attack of Plant Disturbing Organisms (OPT). the optimal use of seed quantities is needed for rice cultivation, in order to reduce the use of seed quantities. Based on the results of the practice in the field that the use of seeds at the farmer level is still relatively high reaching $40 \mathrm{~kg}$ ha- 1 , this is due to the use of seeds that are quite high, namely 5-10 seeds per planting hole. The use of a lot of seeds, in plants there will be competition in the extraction of nutrients, absorption of water, absorption of the intensity of daylight, oxygen as a result of the plant space to grow to be limited. The purpose of this study is to obtain new superior varieties that are adaptive with a high level of productivity, get one component of the appropriate technology package, especially in the use of appropriate number of seedlings based on location specifics and produce a combination of technological packages between varieties and the number of suitable seeds to increase productivity lowland rice.

\section{Research Methods}

This research was conducted in Lumut Village, Toba District, Kab. Sanggau, from May to September 2016. The seeds used are Ciherang Varieties, Inpari 30 and Inpara 2. Seed treatments are carried out using a salt solution then sown on the seedling media in the form of a prepared bed. Land processing is carried out in an imperfect or method, minimum tillage meaning that land processing is only one time directly glazed without being cut off, because the paddy field is a former swamp land which has a shallow pyrite layer. Planting is done at the age of the seedlings 20 days after the seedling. Basic fertilization is carried out when the plants are 10 days after planting (DAP), namely SP-36 $20 \mathrm{~kg} \mathrm{ha}^{-1}$, Urea $50 \mathrm{~kg} \mathrm{ha}^{-1}$ and NPK Mutiara 16:16:16 $100 \mathrm{~kg} \mathrm{ha}^{-}$ 1. I followed fertilization at the age of 30 days, with Pearl urea and NPK fertilizers each dose of $50 \mathrm{~kg} \mathrm{ha}^{-1}$ and $100 \mathrm{~kg} \mathrm{ha}^{-1}$. Secondary fertilization was carried out at the age of 42 days, with Pearl urea and NPK fertilizers each dose of $50 \mathrm{~kg} \mathrm{ha}^{-1}$ and $100 \mathrm{~kg} \mathrm{ha}^{-1}$.

This study uses factorial Randomized Block Design (RBD) consisting of 2 factors, namely the first factor of the variety and the second factor for the use of the number of seeds. The treatment is as follows:

Factor I. Varieties (V) consisting of 3 varieties, namely:

$\mathrm{V} 1=$ Ciherang

$\mathrm{V} 2$ = Inpari 30

$\mathrm{V} 3=$ Inpara 2

Factor II. Number of seeds consisting of 4 levels, namely:

B2 $=2$ seeds per planting hole

B5 $=5$ seeds per planting hole 
$\mathrm{B} 8=8$ seeds per planting hole

B11 = 11 seeds per planting hole

From the two factors mentioned above there are 12 treatment combinations which are repeated as many as 3 times resulting in 36 treatment plots. The combination of treatments is presented in Table 1.

Table 1: Combination of varieties and number of seeds.

\begin{tabular}{|l|c|c|c|c|}
\hline Treatment of Varieties & \multicolumn{4}{|c|}{ Treatment Amount of Seeds } \\
\cline { 2 - 5 } & 2 seedlings (B2) & 5 seeds (B5) & 8 seeds (B8) & 11 seeds (B11) \\
\hline Ciherang (V1) & V1 B2 & V1 B5 & V1 B8 & V1 B11 \\
Inpari 30 (V2) & V2 B2 & V2 B5 & V2 B8B8 & V2V2 B11 \\
Inpara 2 (V3) & V3 B2 & V3 B5 & V3 B8 & V3 B11 \\
\hline
\end{tabular}

Variables observed were (1) panicles per clump (panicles), (2) panicle length $(\mathrm{cm}),(3)$ number of filled grains per panicle (grain), (4) Percentage of empty grain (\%), (5) number of grain per panicle (grain) (6) weight of 1000 grains (g), and (7) yield of harvested dry grain $\left(\mathrm{t} \mathrm{ha}^{-1}\right)$. Data were analyzed using the $\mathrm{F}$ test and if it showed significant differences, then the test was continued with BNT level of $5 \%$, to find out the difference in influence between treatments.

\section{Results and Discussion}

\section{Varieties}

The data in Table 2 below shows that based on the results of the statistical analysis of varieties it has a significant effect on the average panicle length, number of filled grains per panicle, percentage of empty grain, number of grain per clump and yield. While the number of panicles per clump does not differ between varieties.

Table 2: Average number of panicles per clump, panicle length, number of filled grains per panicle, percentage of empty grain, number of grains per panicle and yields of dry grain yields on new improved varieties of wet rice.

\begin{tabular}{|l|c|c|c|c|c|c|}
\hline $\begin{array}{l}\text { Treatment } \\
\text { of }\end{array}$ & $\begin{array}{c}\text { Number of } \\
\text { panicles per } \\
\text { clump } \\
\text { (panicle) }\end{array}$ & $\begin{array}{c}\text { Panicle } \\
\text { length } \\
(\mathbf{c m})\end{array}$ & $\begin{array}{c}\text { Amount of } \\
\text { filled grain } \\
\text { per panicle } \\
\text { (item) }\end{array}$ & $\begin{array}{c}\text { Percentage of } \\
\text { empty grain } \\
(\boldsymbol{\%})\end{array}$ & $\begin{array}{c}\text { Amount of } \\
\text { grain per } \\
\text { panicle } \\
\text { (item) }\end{array}$ & $\begin{array}{c}\text { Production } \\
\text { Results } \\
\text { (t ha-1) } \\
\text { GKP }\end{array}$ \\
\hline Ciherang & $13.58 \mathrm{a}$ & $17,68 \mathrm{~b}$ & $53.56 \mathrm{~b}$ & $11.53 \mathrm{~b}$ & $60.50 \mathrm{~b}$ & $3.392 \mathrm{~b}$ \\
\hline Inpari 30 & $15.25 \mathrm{a}$ & $16.57 \mathrm{c}$ & $54.92 \mathrm{~b}$ & $12.93 \mathrm{~b}$ & $62.49 \mathrm{~b}$ & $4.030 \mathrm{~b}$ \\
\hline Inpara 2 & $15.45 \mathrm{a}$ & $19.01 \mathrm{a}$ & $75,13 \mathrm{a}$ & $26.26 \mathrm{a}$ & $98.42 \mathrm{a}$ & $5.369 \mathrm{a}$ \\
\hline
\end{tabular}

Information: Numbers accompanied by the same letters in the same column mean that they are not significantly different according to the 5\% BNT test.

The number of panicles per clump based on the results of statistical analysis there is no difference between the varieties of Inpara 2 with Ciherang and Inpari 30, but from the average value of the varieties Inpara 2, higher is 15.45 panicles while Ciherang and Inpari 30 are 13.58 and 15.25 panicles (Table 2). The adaptation test of new superior varieties of wetland rice in Morokai, Central Maluku showed that the number of productive tillers for the Ciherang variety was 11 tillers and classified as lower than the other varieties (Kaihatu and Pesireron, 2011). The Ciherang variety 
which was planted in intensive paddy fields in the prime location of the Waenetat village farm, Waepo Subdistrict has 11 productive tillers (Sirapah, 2011). Inpara 2 varieties planted in Entikong Subdistrict have panicles per clump almost the same as the results of the study, which is 14.08 panicles (Sution et al., 2017).

The panicle length based on the results of the analysis shows that the Inpara 2 variety has longer panicles than the Ciherang and Inpari 30 varieties which are $19.01 \mathrm{~cm}$, while Ciherang and Inpari 30 are $17.68 \mathrm{~cm}$ and $16.57 \mathrm{~cm}$ respectively (Table 2). The panicle length indirectly affects the number of panicles, because the longer the panicle has the chance of more grains. Panicle length is significantly affected by differences in genotype and plant population (Sutaryo et al., 2014). One of the observational variables that influence rice productivity is the number of filled grains per panicle, the percentage of empty grain and the number of grain per panicle, based on the results of statistical analysis which have the same pattern, namely the highest in Inpara 2 variety, while the same Ciherang and Inpari 30 varieties do not differ between varieties (Table 1). The number of filled grains per panicle of Inpara 2 varieties (75.13 grains), Inpari 30 (54.92 grains) and Ciherang (53.56 grains). The number of filled grain per panicle test results of adaptation of new superior varieties carried out in the border area of West Kalimantan, namely Entikong Sub district that the Inpara 2 variety of fill grain is higher than the Inpari 7, Inpari 8, Inpari 10, Inpari 20, and Cibogo varieties respectively 86, 11 items, 71.21 grains, 79.03 grains, 81.05 grains, 80.53 grains and 70.73 grains (Sution et al., 2017). The amount of filled grain per panicle is significantly related to crop yields but is strongly influenced by hollow grain. The number of filled grain per panicle has a real correlation with the results, so the number of filled grain per panicle is one of the reference criteria for selection to get high yields (Bobihoe and Jumakir, 2011).

The percentage of empty grain was highest in Inpara 2 varieties $(26.26 \%)$ while Ciherang and Inpari 30 varieties were $11.53 \%$ and $12.93 \%$ respectively. According to Sution et al., (2017) that the variety of Inpara 2 has a percentage of empty grain by $20.76 \%$. The percentage of empty grain will affect the yield of rice plants, because the higher the percentage of grain, the greater the effect on rice yield, where the higher the empty grain results in low rice production. Empty grains show the inability of plants to replenish plants, can be caused by environmental factors.

The results of the variance analysis showed that the highest adaptation test for new superior varieties was in the Inpara 2 variety compared to the Ciherang and Inoari 30 varieties. The yield per hectare or productivity was a variable measured based on the results of harvested dry grain. To determine the productivity of rice plants, it was carried out using sweet potatoes, for legowo 2: 1 (50-25) x $12.5 \mathrm{~cm}$ using a size of $2 \mathrm{~m} \times 5$ rows of legowo. Table 2 shows that the yields of Inpara 2 varieties are higher than those of the Ciherang and Inpari 30 varieties, respectively $5.37 \mathrm{t}$ ha-1, $3.39 \mathrm{t}$ ha-1, and $4.00 \mathrm{t}$ ha- 1 . The test results of rice paddy varieties carried out in Entikong show that the Inpara 2 variety has yields of $6.97 \mathrm{t}$ ha-1. Rice plants have the highest potential genetic yield which is the limit of the ability of a variety in producing grain, which can be achieved if climate factors support and without limiting environmental factors (Makarim and Suhartatik, 2009).

\section{Number of Seeds}

Data in Table 3 shows that based on the results of statistical analysis, with treatment using several numbers of seeds does not significantly affect the number of panicles per clump, panicle length, 
percentage of empty grain and yield of harvested dry grain. However, the highest number of filled grains was treated with 8 stems, while the highest number of grains per panicle was treated with 2 stems and 8 stems.

Table 3: The average number of panicles per clump, panicle length, number of filled grains per panicle, percentage of empty grain, number of grains per panicle and yields of dry grain productivity of the number of seeds.

\begin{tabular}{|l|c|c|c|c|c|c|}
\hline Treatment of & $\begin{array}{c}\text { Number of } \\
\text { panicles } \\
\text { per clump } \\
\text { (panicle) }\end{array}$ & $\begin{array}{c}\text { Panicle } \\
\text { length } \\
(\mathbf{c m})\end{array}$ & $\begin{array}{c}\text { Amount of } \\
\text { filled grain } \\
\text { per panicle } \\
\text { (item) }\end{array}$ & $\begin{array}{c}\text { Percentage of } \\
\text { empty grain } \\
(\%)\end{array}$ & $\begin{array}{c}\text { Amount of } \\
\text { grain per } \\
\text { panicle } \\
\text { (item) }\end{array}$ & $\begin{array}{c}\text { Production } \\
\text { Results } \\
\text { (t ha-1) }\end{array}$ \\
\hline 2 stem seeds & $14,89 \mathrm{a}$ & $18,04 \mathrm{a}$ & $64.78 \mathrm{~b}$ & $15.08 \mathrm{a}$ & $76.14 \mathrm{a}$ & $4,635 \mathrm{a}$ \\
\hline 5 stem seeds & $14,89 \mathrm{a}$ & $17.90 \mathrm{a}$ & $\mathrm{b}$ & $59,9918,84 \mathrm{a}$ & $73,99 \mathrm{ab}$ & $4,259 \mathrm{a}$ \\
\hline 8 stem seeds & $14,89 \mathrm{a}$ & $17,68 \mathrm{a}$ & $65.56 \mathrm{a}$ & $17.02 \mathrm{a}$ & $78.69 \mathrm{a}$ & $4.642 \mathrm{a}$ \\
\hline 11 stem seeds & $14.33 \mathrm{a}$ & $17.40 \mathrm{a}$ & $54.43 \mathrm{~b}$ & $17.48 \mathrm{a}$ & $66.39 \mathrm{~b}$ & $3.519 \mathrm{a}$ \\
\hline
\end{tabular}

Description: Figures accompanied by the same letter in the column the same means that it is not significantly different according to the $5 \%$ BNT test.

The data in Table 3 above shows that by using 2 stem seeds, 5 stem seeds, 8 stem seeds, and 11 stem seeds, the statistical analysis has the same panicle number. The number of panicles per clump is one component that affects the productivity of rice plants. The number of panicles per clump, the higher the potential to produce grain, so the potential yield per unit area is also higher. According to Atman (2007) that by treating the number of seedlings 1 - 9 stems against the number of productive tillers which depicted the number of panicles per clump was not significant between treatments. This is in line with the results of this study there is no difference between the number of seeds to the number of panicles produced.

Table 3 shows that panicle length does not differ between the treatments for the number of seeds of 2 - 11 stems. Panicle length indirectly affects the amount of grain per panicle. The research results which are almost the same are shown by Amtan (2007) that with the treatment of seeds 1 9 stems there was no significant difference between the panicle length. The more the number of panicles per $\mathrm{m} 2$ by increasing the plant population, the shorter panicles produced, otherwise the longer the average panicle rice crop, the more the amount of grain produced (Yoshida, 1981).

The data in Table 3 shows that the highest number of filled grain in the treatment with the number of 8 stem seeds is 65.56 grains, while for the number of seeds 2 stems, 5 stems and 11 stems 64.78 grains, 59.99 grains and 54, respectively. 43 items. Based on the results of the study of the amount of grain, in general, it is still low because at that location has a fairly high iron element, especially in the maximum vegetative phase because of less rainfall, washing iron on the land is not smooth. A somewhat different condition is produced by Atman (2007) that statistical analysis of rice grain did not differ between treatments, but the highest was observed in the treatment of 5 stem seeds per planting hole.

The data in Table 3 shows that the percentage of empty grain does not have a significant difference between the treatment of the number of seeds 2 stems, 5 stems, 8 stems and 11 stems $15.08 \%$, $18.84 \%, 17.02 \%$, and $17.48 \%$. The percentage of empty grain will affect the yield of rice plants, because the higher the percentage of grain, the greater the effect on rice yield, where the higher 
the empty grain results in low rice production. Empty grains show the inability of plants to replenish plants, can be caused by environmental factors.

The data in Table 3 shows that the number of grains per panicle is the least with the number of seedlings of 11 stems, namely 66.39 grains, while for the number of seeds 2 stems, 5 stems and 8 stems every 76.14 grains, 73.99 grains and 78, 69 items. The amount of grain per panicle indirectly affects the yield component because as much grain is produced in one panicle, there is more potential for grain content per panicle.

The data on Table 3 shows that the yield of harvested dry grain based on statistical analysis does not have a significant difference between the treatment of the number of seeds of 2 stems, 5 stems, 8 stems and 11 stems $4.635 \mathrm{t}$ ha- $1,4,259 \mathrm{t}$ ha-1, 4,642 $\mathrm{t}$ ha-1, and 3,519 t ha- 1 . The results showed that the number of seeds from 2 to 11 stems had the same productivity. Use of the number of seeds per planting hole based on the concept of Integrated Crop Management (PTT), which is 1-3 sticks. Based on the results of the study there are uses of the number of seeds having different production results. This might be due to the suitability of the varieties in the environment. According to Atman (2007), by using 1 stalk per seedling plant, yields lower productivity compared to 3 - 9 seeds. Added by Ridwan and Munir (2004) that the yield of the best Cisokan varieties using the number of seeds 5 stems per planting hole. Misran (2014) states that with the use of seeds 1-5 stems per planting hole it gives the best results, whereas, with the use of above seeds 7 stems per plant hole, there is a tendency to decrease production yield.

The use of many seeds per planting hole can affect competition between plants in absorbing nutrients, water, daylight radiation, and oxygen. The increase in the number of seeds per plant tends to increase competition between plants in one clump and with other clumps of light, space, and nutrients which affect growth and production (Muyassir, 2012). The amount of nutrients needed by plants is closely related to the needs of plants to grow better, if the amount of nutrients is less available then growth will be hampered, but if the amount of nutrients available is higher than the number of nutrient requirements by plants it can be said as a condition of luxury consumption (Lakitan, 2008).

\section{Interaction Between Treatments}

The results of the variance analysis showed that the weight of 1000 grains was influenced by the interaction between the varieties and the number of seeds (Table 4). The highest grain weight of 1000 grains was treated by Inpara 2 variety with 2 stems and 5 stems.

Table 4: The average weight of 1000 grains due to the treatment of varieties and number of seeds.

\begin{tabular}{|l|c|c|c|c|}
\hline \multirow{2}{*}{ Varieties } & \multicolumn{4}{|c|}{ Number of seeds } \\
\cline { 2 - 5 } & 2 seeds (B2) & 5 seeds (B5) & 8 seeds (B8) & 11 seeds (B11) \\
\hline Ciherang (V1) & $23.99 \mathrm{abcd}$ & $24.66 \mathrm{abcd}$ & $24.74 \mathrm{abcd}$ & $23.33 \mathrm{bcd}$ \\
\hline Inpari 30 (V2) & $25,89 \mathrm{a}$ & $25.81 \mathrm{a}$ & $25.25 \mathrm{ab}$ & $22.84 \mathrm{~d}$ \\
\hline Inpara 2 (V3) & $23.08 \mathrm{~cd}$ & $24.91 \mathrm{abc}$ & $23.59 \mathrm{bcd}$ & $23.16 \mathrm{~cd}$ \\
\hline
\end{tabular}

Description: Numbers accompanied by the same letters in the same column mean that they are not significantly different according to the 5\% BNT test.

The grain weight of 1000 grains represents the size of rice grains. Grain size is influenced by genetic traits and adaptability to the growing environment. The size of the grain size can be 
affected by the occurrence of competition for large numbers of tillers resulting in competition in the absorption of nutrients (Kaihatu and Pasireron, 2011). The weight of 1000 grains for the number of seeds per planting hole of 1 - 9 stems does not have differences between treatment (Atman 2007; Misran, 2014).

\section{Conclusion}

1) Inpara 2 varieties were significantly higher than Ciherang and Inpari 30 varieties for panicle length characters, number of Gaba contents per panicle, percentage of empty grain, number of grain per panicle and increased the productivity of $24.94 \%$ of harvested dry grain.

2) The use of the number of seeds per planting hole did not affect the panicle length, the number of panicles per clump, percentage of empty grain and yields of harvested dry grain.

3) The use of 8 stems per planting hole showed a significantly higher yield for the character of the number of filled grains and the number of grains per panicle.

4) The use of Inpari 30 varieties with the number of seeds of 2-5 stems can increase the grain weight of 1000 grains to $25.89 \mathrm{~g}$ and $25.81 \mathrm{~g}$.

\section{Conflict of Interest}

The authors declared that present study was performed in absence of any conflict of interest”.

\section{Acknowlegement}

Thank you for the Assessment Institute for Agricultural Technology of Wast Kalimantan, and the Agriculture Service of Sanggau District, West Kalimantan, Indonesia. The results of this study are dedicated to the development of science

\section{Author Contributions}

$\mathrm{S}$ design and conduct research, data collection, data analysis and also manuscript writing. LL designs and conducts research, reviewing manuscripts and submit manuscripts.

\section{References}

[1] Atman. 2007. Varietas Unggul Baru Padi sawah Batang Lembang: Deskripsi dan Teknologi Budidaya. J. Ilmiah Tambua 6(2): 153-162.

[2] Bobihoe, J., dan Jumakir. 2011. Uji Adaptasi Beberapa Varietas Unggul Baru (VUB) Padi Sawah di Provinsi Jambi. Prosiding Seminar Nasional Pengkajian dan Diseminasi Inovasi Pertanian Menduking Program Strategi Kementrian Pertanian Buku 3, Cisarua 9-11 Desember 2010. Balai Besar Pengkajian dan Pengembangan Teknologi Pertanian. Bogor.

[3] Kaihatu, S.S. dan M. Pesireron. 2011. Adaptasi Beberapa Varietas Unggul Baru Padi Sawah Di Morokai. Adaptation some of upland rice superior variety at morokai. J. Agrivigor 11(2): 178-184.

[4] Kementerian Pertanian. 2015. Rencana Strategis Kementerian Pertanian 2015-2019. Jakarta. p. 208.

[5] Kiswanto dan F.Y. Adriyani. 2011. Uji Adaptasi Varietas Unggul Baru Padi Sawah di Kecamatan Pubiana Lampung Tengah. Prosiding Seminar Nasional Pengkajian dan Diseminasi Inovasi 
Pertanian Menduking Program Strategi Kementrian Pertanian Buku 2, Cisarua 9-11 Desember 2010. Balai Besar Pengkajian dan Pengembangan Teknologi Pertanian. Bogor.

[6] Lakitan, B. 2008. Dasar-Dasar Fisiologi Tumbuhan. Raja Grafindo Persada, Jakarta.

[7] Makarim, A.K dan E. Suhartatik. 2009. Morfologi dan Fisiologi Tanaman Padi. Padi Inovasi Teknologi Produksi Buku 2. Balai Besar Penelitian Tanaman Padi. Badan Penelitian dan Pengembangan Pertanian. Sukamandi. 295-329.

[8] Misran. 2014. Efesiensi Penggunaan Jumlah Benih Terhadap Pertumbuhan dan Produksi Padi sawah. J. Penelitian Pertanian Terapan 14(1): 39-43.

[9] Muyassir. 2012. Efek Jarak Tanam, Umur dan Jumlah Bibit Terhadap Hasil Padi Sawah (Oryza sativa L.). J. Manajemen Sumberdaya Lahan 1(2): 207-212.

[10] Ridwan dan R. Munir. 2004. Pengaruh Umur dan Jumlah Bibit per Rumpun Terhadap Pertumbuhan dan Hasil Padi Sawah Sistem Tanam Pindah. J. Ilmiah Tambua 3(3): 137-140.

[11] Sirappa, M.P., 2011. Kajian Perbaikan Teknologi Budidaya Padi Melalui Penggunaan Varietas Unggul Dan Sistem Tanam Jajar Legowo Dalam Meningkatkan Produktivitas Padi Mendukung Swasembada Pangan. J. Budidaya Pertanian 7(2): 79-86.

[12] Suprihatno, B. dan A.A. Daradjat. 2009. Kemajuan dan Ketersediaan Varietas Unggul Padi Buku 1. Balai Besar Penelitian Tanaman Padi. Sukamandi. 331-352.

[13] Sutaryo, B., Sudarmaji dan Sarjiman. 2014. Penampilan Fenotipe Empat Varietas Unggul Baru Padi Pada Tiga Sistem Tanam Yang Berbeda. Prosiding Seminar Nasional 2013. Inovasi Teknologi Padi Adaptif Perubahan Iklim Global Mendukung Surplus 10 Juta Ton Beras Tahun 2014. Buku 2. Badan Penelitian dan Pengembangan Pertanian. Kementerian Pertanian. Sukamandi.575-584.

[14] Sution, T. Sugiarti dan Serom. 2017. Kajian Adaptasi Enam Varietas Unggul Baru Padi sawah Irigasi Semi Teknis di Daerah Perbatasan Kalimantan Barat. Prosiding Seminar Nasional 2016. Inovasi Teknologi Pertanian Spesifik Lokasi "Inovasi Teknologi Pertanian Spesifik Lokasi Mendukung Kedaulatan Pangan Berkelanjutan". Balai Besar Pengkajian dan Pengembangan Teknologi Pertanian. Badan Penelitian dan pengembangan Pertanian. Kementerian Pertanian. Banjarbaru.

[15] Yoshida, S. 1981. Fundamentals of Rice Crop Science. Internasional Rice Research Institute. Los Banos.

*Corresponding author.

E-mail address: laurensiusl@ yahoo.co.id 